\title{
Procalcitonin as a diagnostic and prognostic marker in diabetic foot infection. A current literature review
}

\author{
DIMITRIOS VELISSARIS ${ }^{1 *}$, NIKOLAOS-DIMITRIOS PANTZARIS ${ }^{1,}{ }^{*}$, CHRISTINA PLATANAKI $^{1}$, \\ NIKOLINA ANTONOPOULOU ${ }^{1}$, CHARALAMPOS GOGOS ${ }^{1}$ \\ ${ }^{1}$ Internal Medicine Department, University Hospital of Patras, Greece \\ * The two first authors of this article contributed equally and are listed as first co-authors
}

\begin{abstract}
Diabetic foot ulcers (DFUs) are a very common cause of mortality and morbidity. The distinction between infected and non-infected DFU remains a very challenging task for clinicians in everyday practice. Even when infection is documented, the spectrum of diabetic foot infection is wide, ranging from cellulitis and soft tissue infection to osteomyelitis. Procalcitonin (PCT), a wellestablished sepsis biomarker, has been used in the diagnosis of several infections including osteomyelitis in patients with diabetes mellitus. This review gathers and presents all the relevant data, up until now, regarding the use of PCT as an assessment tool in diabetic patients with foot infection. Current evidence suggests that PCT levels could aid clinicians in distinguishing infected from noninfected DFUs as well as in the distinction between soft tissue infection and bone involvement, but further and larger studies are warranted to confirm these findings.
\end{abstract}

Key words: diabetic foot; diabetic foot infection; diabetic foot ulcer; diabetes mellitus; diabetic foot osteomyelitis; inflammatory biomarkers; osteomyelitis; procalcitonin.

\section{INTRODUCTION}

Diabetic foot ulcer (DFU) is one of the most common problems clinicians have to deal within patients with diabetes mellitus (DM). The incidence varies between $15 \%$ and $25 \%$, and about $1 \%$ of this population has to undergo a lower limb amputation [1]. The high incidence of severe complications and the increased rates of morbidity and mortality, prompt for early diagnosis and initiation of appropriate antibiotic treatment to improve final outcomes.

Infection complicates approximately $60 \%$ of DFUs. The initial soft tissue infection may spread into the bone resulting in diabetic foot osteomyelitis and thus a high risk of amputation. Osteomyelitis should be suspected in all DFU patients with clinical findings of infection and in chronic or recurrent wounds [2]. Early identification of this clinical entity is crucial for the overall management and in order to reduce mortality [3].

Procalcitonin (PCT), a precursor of calcitonin, is a 116 amino-acid peptide, member of the calcitonin superfamily of peptides. Its normal serum concentrations are $<0.05 \mathrm{ng} / \mathrm{mL}$. PCT is released from the thyroidal $\mathrm{C}$ cells and is the precursor of Calcitonin. Liver, lung and kidney parenchymal cells are also the principal source of circulating PCT in sepsis.
PCT is an acute-phase protein with faster kinetics than C-reactive protein (CRP) and erythrocyte sedimentation rate (ESR) and it is detectable within 4-6 hours in the serum after the onset of a bacterial infection. Its peak in the serum is identified within $24 \mathrm{~h}$ and then its levels start to decline following effective treatment [4-6].

PCT has been used as a sepsis biomarker in several infections including osteomyelitis in patients with diabetes mellitus. The aim of the current review is to summarize the existing literature referring to the role of PCT as a diagnostic and prognostic tool in the management of diabetics with foot infection. A Pubmed/Medline search was conducted from inception to August 2017, applying no language restrictions. The search terms used were ("calcitonin" [MeSH Terms] OR "calcitonin" [All Fields] OR "procalcitonin" [All Fields]) AND ("osteomyelitis" [MeSH Terms] OR "osteomyelitis" [All Fields]) OR ("calcitonin" [MeSH Terms] OR "calcitonin" [All Fields] OR "procalcitonin" [All Fields]) AND ("diabetic foot" [MeSH Terms] OR ("diabetic" [All Fields] AND "foot" [All Fields]) OR "diabetic foot" [All Fields]).

A total of 41 articles were originally retrieved. All original studies examining PCT serum levels in adult patients with diabetes mellitus and foot ulcers 
were included. Bibliographies from the extracted articles were also reviewed to identify any additional relevant publications. This resulted in a total of 15 clinical studies and 1 meta-analysis.

\section{DIAGNOSIS IN DIABETIC FOOT INFECTIONS}

Diagnosing the presence of infection in the foot of a patient with diabetes can sometimes be a difficult task, particularly in cases of underlying osteomyelitis. Evaluation of osteomyelitis should involve a precise examination of the extremity for clinical signs of infection (purulent secretion, warmth, redness, tenderness, pain, induration) in combination with appropriate laboratory and imaging findings.

Open wounds are always colonized by microorganisms and infection should be considered in the presence of systemic or local signs of inflammation. Patients' medical history and physical examination constitute the initial approach. Serological tests may be helpful, especially the measurement of the blood white cell (WBC) count, ESR, CRP and PCT values, but all seem to be relatively non-specific in nature.

Cultures of properly obtained soft tissue and bone specimens, along with newer molecular microbial techniques, which identify more organisms, virulence factors, and antibiotic resistance, are useful in the diagnosis of diabetic foot infections. Microbiological data such as deep swabs and transcutaneous bone biopsy are considered the ideal methods of obtaining the necessary information when osteomyelitis in diabetics is suspected [7].

Imaging tests generally begin with plain X-rays, but when more details of bone or soft tissue abnormalities are required, advanced studies are needed. Among these, Magnetic resonance imaging is considered the gold standard in diagnosing osteomyelitis, despite its variable sensitivity and specificity [8].

Despite many years of research, no single sufficient criterion has been developed to diagnose osteomyelitis in diabetics and a combination of different diagnostic tools has been used.

\section{BIOMARKERS AND DIABETIC FOOT INFECTION}

Several biomarkers have been used in the detection and the evaluation of the complications of diabetes. Based on the underlying pathophysiologic mechanisms of the disease, atrial natriuretic peptide, galectin-3 and cardiac troponins are used for asses- sment of diabetic cardiomyopathy, cystatin $\mathrm{C}$ for diabetic nephropathy, while CRP and PCT could be helpful in early and noninvasive diagnosis of infection especially when clinical signs are misleading [9]. The laboratory markers of inflammation commonly used worldwide, such as peripheral leukocyte count, ESR, CRP, and PCT, may provide useful information in the diagnosis of soft tissue and bone infection.

Although there is sufficient evidence supporting that laboratory findings can be helpful in diagnosing and monitoring diabetic foot infection, these should be used as an integrated modality in clinical practice rather than as differentiating findings. These markers alone should not be used to establish a diabetic foot infection diagnosis as they are non-specific and a predictive role of new biomarkers is still warranted [10]. In any case, a decline in levels of serum markers can be used to monitor success of therapy [11].

\section{PROCALCITONIN IN THE DIAGNOSIS OF DIABETIC FOOT INFECTION}

PCT is considered a sensitive and specific marker of many bacterial infections, and it has also been used as a potential tool for assessing disease severity and differentiating bacterial infection from non-infective causes of inflammation and viral infections [12]. Serial measurements of its serum levels are considered a useful tool for monitoring the response to therapy [13].

Although serum PCT is an established diagnostic biomarker for sepsis and septic shock, data regarding localized infections are limited. Levels of serum PCT are variable and depend on the site and extent of the infection. In patients with localized infections serum PCT levels are in general lower compared to those with systemic bacterial infections [14].

Regarding bone and joint infections, no specific laboratory tests for the diagnosis exist, except for the isolation of a microorganism from the bone or the synovial fluid which is the gold standard, albeit with variable sensitivity ( $30 \%$ to $90 \%$ ). Early identification of skeletal infection remains a challenge for clinicians, especially in cases involving particular populations such as the diabetics. In such cases the evaluation of serum PCT levels seems to have a crucial role.

Serum biomarkers like WBC count and CRP are helpful but are not specific. PCT serum level is very low in healthy patients $(<0.1 \mathrm{ng} / \mathrm{mL})$ and rises rapidly in response to bacterial endotoxins 
[15]. However, in the cases of diabetic foot infection, inflammatory markers combined to extracted findings of clinical assessment seem to be of great importance in the diagnosis and treatment.

The diagnostic performance of PCT in diabetic foot infection had not been elucidated in extent previously. Its diagnostic role is uncertain, while a limited number of studies is available in this regard. All the clinical studies published up to August 2017, along with their relevant data regarding the use of PCT in the diagnosis of diabetic foot infection, are presented in Table 1.

Table 1

Summary of studies

\begin{tabular}{|c|c|c|c|}
\hline First Author & $\begin{array}{l}\text { Publication } \\
\text { Year/Country } \\
\text { Design }\end{array}$ & Participants/Arms & Relative Findings \\
\hline $\begin{array}{l}\text { Al-Shammaree SAW } \\
{[16]}\end{array}$ & $\begin{array}{l}\text { 2017/Iraq } \\
\text { Case-control }\end{array}$ & $\begin{array}{l}88 \text { DM \& Healthy Controls } \\
\text { - } 16 \text { healthy } \\
\text { - } 17 \text { DM without DFU } \\
\text { - } 25 \text { with non-infected DFU } \\
\text { - } 30 \text { with infected DFU }\end{array}$ & $\begin{array}{l}\text { PCT levels were significantly higher in the infected DFU } \\
\text { group when compared to the other groups. }\end{array}$ \\
\hline Umapathy D [17] & $\begin{array}{l}\text { 2017/India } \\
\text { Cross-sectional }\end{array}$ & $\begin{array}{l}185 \text { DM } \\
\text { - } 75 \text { without DFU } \\
\text { - } 34 \text { with non-infected DFU } \\
\text { - } 76 \text { with infected DFU } \\
\end{array}$ & $\begin{array}{l}\text { PCT with a cut-off value of } \geq 0.5 \mathrm{ng} / \mathrm{mL} \text { has a higher } \\
\text { sensitivity and specificity than CRP, WBC count and ESR as a } \\
\text { diagnostic marker for infected DFU. }\end{array}$ \\
\hline Ingram JR [18] & $\begin{array}{l}\text { 2017/UK } \\
\text { Case-control }\end{array}$ & $\begin{array}{l}67 \text { DM } \\
\text { - } 29 \text { with infected DFU } \\
\text { - } 38 \text { with non-infected DFU }\end{array}$ & $\begin{array}{l}\text { Serum PCT does not help to distinguish uninfected from } \\
\text { mildly infected diabetic foot ulcers. }\end{array}$ \\
\hline Yang Q [19] & $\begin{array}{l}\text { 2017/China } \\
\text { Case-control }\end{array}$ & $\begin{array}{l}\text { 65 with Wagner Grade-4 DFU } \\
\text { - } 32 \text { thorough debridement } \\
\text { - } 33 \text { minor debridement } \\
\end{array}$ & $\begin{array}{l}\text { PCT levels within seven days were higher in the thorough } \\
\text { debridement group than in the minor debridement group. }\end{array}$ \\
\hline Massara M [9] & $\begin{array}{l}\text { 2017/Italy } \\
\text { Case-control }\end{array}$ & $\begin{array}{l}30 \text { DM } \\
\text { - } 15 \text { with infected DFU } \\
\text { - } 15 \text { with non-infected DFU }\end{array}$ & $\begin{array}{l}\text { PCT was the most efficient biomarker in the diagnosis of } \\
\text { infected DFU. Sensitivity is increased when PCT is combined } \\
\text { with CRP or ESR }\end{array}$ \\
\hline Park JH [20] & $\begin{array}{l}\text { 2017/South Korea } \\
\text { Prospective cohort }\end{array}$ & 123 DM hospitalized for infected DFU & $\begin{array}{l}\text { PCT and CRP levels were significantly associated with } \\
\text { infection severity in DFU. PCT levels }>0.59 \mathrm{ng} / \mathrm{mL} \text { in patients } \\
\text { with infected DFU may be associated with concomitant } \\
\text { systemic bacterial infection. }\end{array}$ \\
\hline Van Asten SA [11] & $\begin{array}{l}\text { 2017/USA } \\
\text { Prospective cohort }\end{array}$ & $\begin{array}{l}5 \mathrm{DM} \\
\text { - } 24 \text { diabetic foot osteomyelitis } \\
\text { - } 11 \text { diabetic foot no osteomyelitis }\end{array}$ & $\begin{array}{l}\text { PCT levels in the osteomyelitis subgroup were significantly } \\
\text { higher at baseline than in the subgroup with no osteomyelitis } \\
(\mathrm{p}<0.05) \text {. }\end{array}$ \\
\hline Reiner MM[21] & $\begin{array}{l}\text { 2017/USA } \\
\text { Case-control }\end{array}$ & $\begin{array}{l}156 \text { with lower extremity infection in } \\
\text { which surgical intervention was required. }\end{array}$ & $\begin{array}{l}\text { Patients who underwent below-the-knee or above-the-knee } \\
\text { amputation had significantly higher initial PCT levels. }\end{array}$ \\
\hline Karakas A [22] & $\begin{array}{l}\text { 2014/Turkey } \\
\text { Case-control }\end{array}$ & $\begin{array}{l}27 \text { with DFU } \\
\text { - } 6 \text { amputation } \\
\text { - } 21 \text { non-amputation } \\
\end{array}$ & $\begin{array}{l}\text { Initial (admission) PCT levels did not significantly differ } \\
\text { between the amputation and the non-amputation group. }\end{array}$ \\
\hline Jonaidi Jafari N [23] & $\begin{array}{l}\text { 2014/Iran } \\
\text { Case-control }\end{array}$ & $\begin{array}{l}\text { 90 DM \& Healthy Controls } \\
\text { - } 30 \text { healthy } \\
\text { - } 30 \text { with infected DFU } \\
\text { - } 30 \text { with non-infected DFU }\end{array}$ & $\begin{array}{l}\text { PCT levels in the infected DFU group were significantly } \\
\text { higher than the non-infected DFU and the control groups } \\
(\mathrm{p}<0.01) \text {. }\end{array}$ \\
\hline Michail M [24] & $\begin{array}{l}\text { 2013/Greece } \\
\text { Prospective } \\
\text { Cohort }\end{array}$ & $\begin{array}{l}\text { 61 DM } \\
\text { - } 34 \text { with soft-tissue infection } \\
\text { - } 27 \text { with osteomyelitis }\end{array}$ & $\begin{array}{l}\text { Initial PCT levels were significantly higher in the osteo- } \\
\text { myelitis group compared to the soft-tissue infection group. }\end{array}$ \\
\hline Altay FA [25] & $\begin{array}{l}\text { 2012/Turkey } \\
\text { Prospective } \\
\text { Cohort }\end{array}$ & 50 with DFU & $\begin{array}{l}\text { Initial PCT levels were positively correlated with CRP and } \\
\text { ESR }(p<0.01) \text {. }\end{array}$ \\
\hline Mutluoğlu M [26] & $\begin{array}{l}\text { 2011/Turkey } \\
\text { Case-control }\end{array}$ & $\begin{array}{l}24 \text { with infected DFU } \\
\text { - } 13 \text { with osteomyelitis } \\
\text { - } 11 \text { without osteomyelitis }\end{array}$ & $\begin{array}{l}\text { PCT levels did not differ with statistical significance between } \\
\text { the osteomyelitis and the non-osteomyelitis group }(p=0.627) \text {. }\end{array}$ \\
\hline Jeandrot A [27] & $\begin{array}{l}\text { 2008/France } \\
\text { Case-control }\end{array}$ & $\begin{array}{l}195 \mathrm{DM} \\
\text { - } 93 \text { with DFU } \\
\text { - } 102 \text { without DFU }\end{array}$ & $\begin{array}{l}\text { PCT and CRP values, when combined, may help in the early } \\
\text { distinction between grade } 1 \text { and } 2 \text { DFU. }\end{array}$ \\
\hline Uzun G [28] & $\begin{array}{l}\text { 2007/Turkey } \\
\text { Case-control }\end{array}$ & $\begin{array}{l}\text { 49 DM\& } 22 \text { healthy controls } \\
\text { - } 27 \text { with infected DFU } \\
\text { - } 22 \text { with non-infected DFU } \\
\text { - } 22 \text { healthy }\end{array}$ & $\begin{array}{l}\text { PCT levels were significantly higher in the infected DFU } \\
\text { group compared to the non-infected DFU subgroup. }\end{array}$ \\
\hline
\end{tabular}

CRP, C-reactive Protein; DFU, Diabetic Foot Ulcer; DM, Diabetes Mellitus; ESR, Erythrocyte Sedimentation Rate; PCT, Procalcitonin. 
Many of the studies reviewed concluded that PCT levels are significantly higher in patients with infected DFUs when compared to patients whose ulcers had not been complicated with an infection [9] [11] [16] [17] [20] [21] [23] [28]. In one of the earlier conducted studies, a case-control by Uzun et al. in 2007, 27 patients with infected DFUs, 22 with non-infected DFUs and 22 healthy controls were recruited. The PCT levels in the infected DFU group were significantly higher than those in the non-infected DFU $(\mathrm{p}<0.001)$ and the control group $(\mathrm{p}<0.001)$. The AUROC for bacterial infection prediction was greater for PCT $(0.859 ; \mathrm{p}<0.001)$ followed by WBC $(0.785 ; \mathrm{p}=0.001)$, ESR $(0.752$; $\mathrm{p}=0.003)$ and CRP $(0.625 ; \mathrm{p}=0.137)$. A cutoff value of $>0.08 \mathrm{ng} / \mathrm{mL}$ had a sensitivity of $77 \%$, a specificity of $100 \%$, a PPV of $100 \%$ and a NPV of $78 \%$ in the diagnosis of diabetic foot infection, though the small number of patients was a limitation in this study [28].

Massara et al. compared 15 diabetics with infected DFUs to 15 with non-infected DFUs and found significantly higher PCT levels in the infected DFU group $(p<0.00001)$, with both groups having similar age and gender characteristics as well as similar comorbidities [9]. Park et al., in a prospective study enrolling 123 patients with infected DFUs, concluded that PCT and CRP were significantly associated with the severity of infection, but only PCT could differentiate patients with systemic infection from patients without a concomitant infection (sensitivity $94.7 \%$, specificity $88.5 \%$, cutoff value $0.59 \mathrm{ng} / \mathrm{mL}, \mathrm{AUC}=0.869 ; \mathrm{p}<0.0001)$ [20].

Al-Shammaree et al. in a 2017 case-control study with four subgroups (healthy, diabetics, infected and non-infected DFU) enrolling 88 subjects, found that PCT levels were significantly higher in the infected DFU group than in the others $(\mathrm{p}<0.01)$. Sensitivity, specificity, the best cutoff value and the area under the curve (AUC) for the diagnostic accuracy of PCT to distinguish infected DFU were $87.5 \%, 86.7 \%, 66.55 \mathrm{pg} / \mathrm{dL}$ and $0.977 ; \mathrm{p}<0.001$ respectively [16].

A case-control study recruiting 30 patients with infected DFUs, 30 with non-infected and 30 healthy controls by Jonaidi Jafari et al. published its results in 2014. The area under the ROC curve to estimate the presence of infection in patients with DFU for PCT was $0.729 ; p<0.001$. A cutoff value of $>$ $0.21 \mathrm{ng} / \mathrm{mL}$ had a sensitivity of $70 \%$, a specificity of $74 \%$, a positive predictive value (PPV) of $70 \%$ and a negative predictive value (NPV) of $50 \%$ in the diagnosis of infected DFU [23]. Both studies of
Al-Shammaree et al. and Jonaidi Jafari et al. confirm that a higher level of serum PCT is present in higher grades of infected DFUs.

Regarding traditional inflammatory biomarkers, in a study by Altay in 2012 with 50 patients with DFU showed a positive correlation between initial PCT levels and CRP $(r=0.56, p<0.001)$ and ESR $(\mathrm{r}=0.49, \mathrm{p}<0.001)$. PCT levels also significantly decreased in the healing patients when compared to the non-healing on the $14^{\text {th }}$ day $(0.05 \mathrm{ng} / \mathrm{mL} \pm 0.02$, and $0.6 \mathrm{ng} / \mathrm{mL} \pm 2.1 \mathrm{p}=0.0070$ ), suggesting PCT as a follow-up marker along with CRP and ESR [25]. Jeandrot in a large case-control study with 195 diabetics published in 2008 proposed that PCT and CRP values, when combined, may help in the early distinction between grade 1 and 2 DFU (noninfected from mildly infected). PCT levels in patients with grade 2 (mildly infected) DFU were significantly higher when compared to those of patients with grade 1 DFU (non-infected) $(\mathrm{p}<0.05)$ or controls $(p<0.05)$.AUROC for the combination of PCT and CRP $(0.947 \pm 0.029)$ was significantly greater than that of either biomarker alone $(p<0.05)$ in the distinction between grade 1 and grade 2 ulcers [27].

A cross-sectional study by Umapathy et al. published in 2017 included 185 individuals with DM dividing them into three groups (DM without DFU, non-infected DFU and infected DFU). PCT was found to be a valid marker in the diagnosis of infected DFU (AUC $=0.99$; 95\% CI, 0.96-1). CRP, ESR, and WBC count were found to be inferior. A serum PCT cutoff value of $\geq 0.5 \mathrm{ng} / \mathrm{mL}$ had $54 \%$ sensitivity, $100 \%$ specificity, PPV of $100 \%$ and a NPV of $12 \%$ in the diagnosis of infected DFU [17].

The possible predictive role of PCT in lower limp amputation has also been investigated. Karakas, in a small case-control pilot study with 27 patients in 2014, did not find PCT levels to be significantly higher in the group of patients who finally underwent amputation $(p=0.157)$ [22]. Notwithstanding, in a 2017 larger case-control study enrolling 156 patients with lower extremity infection in which surgical intervention was required, Reiner found that those who underwent below-the-knee or abovethe-knee amputation had significantly higher initial PCT levels (median $1.72 \mathrm{ng} / \mathrm{mL}$ ) than those who did not (median $0.105 \mathrm{ng} / \mathrm{mL} ; \mathrm{p}<0.001$ ) [21].

Two prospective studies, one by Michail in 2013 and one by Van Asten in 2017 concluded that patients with osteomyelitis had significantly higher PCT levels compared to those with soft tissue infection [11] [24]. Van Asten et al., enrolling 35 patients hospitalized for diabetic foot infection, 
found that PCT is the best marker to differentiate between diabetic foot osteomyelitis and soft tissue infection $(p=0.049)$. The relatively small number of patients without osteomyelitis and the high pretest probability due to the enrolment of patients with ulcers classified as moderate and severe were the limitation of this study [11]. In the study by Michail, 61 diabetic patients with foot infection were recruited. With a cutoff value $>30 \mathrm{ng} / \mathrm{mL}$ of serum PCT, the sensitivity and specificity for the diagnosis of diabetic foot osteomyelitis were $81 \%$ and $71 \%$ respectively [24]. However, Mutluoğlu, in a previous smaller case-control study in 2011, concluded that the difference in PCT levels between the patients with osteomyelitis and those without did not reach statistical significance $(66.7 \pm$ $43.5 \mathrm{pg} / \mathrm{mL}$ and $58.6 \pm 35.5 \mathrm{pg} / \mathrm{mL}$ respectively, $\mathrm{p}=0.627)[26]$.

In a meta-analysis of 8 clinical trials published until July 2014, Van Asten et al. tried to determine which is the best serum biomarker in the diagnosis of diabetic osteomyelitis. Due to the insufficient quantity of data, models did not converge for all biomarkers, including PCT with the exception of ESR. ESR was found to have a pooled sensitivity of $81 \%$ (95\% CI $0.71-0.88)$ and a specificity of $90 \%(95 \%$ CI $0.75-0.96)$ in the diagnosis of diabetic osteomyelitis [29].

\section{CONCLUSIONS}

There is a true need for a sensitive, specific and prognostic marker of bacterial infection in the specific population of diabetics, and the current bibliography emphasizes on the crucial role of PCT in the localized infection of foot ulcers. Though most of the studies are relatively small, evidence is increasing and current data suggests that there is the role for PCT to help clinicians in the diagnosis of infected and non-infected diabetic foot ulcers as well as in the distinction between soft tissue infection and osteomyelitis. Some results also suggest that the predictive role of PCT may be less effective in specific subgroups of patients, like those with mildly infected DFU, and more effective in others (severely infected DFU) [18] [27]. The potential role of specific pathogens and their relation to the diagnostic accuracy of PCT must also be investigated. Future larger and well-designed studies and meta-analyses must prove if the use of PCT can improve the overall medical management and can be used as a prognostic marker of patients with diabetic foot infection as well as define the settings and patients that would benefit the most.

Declaration of Interest: The authors declare that there are no conflicts of interest.

Ulcerul piciorului diabetic (DFU) este o cauză frecventă de mortalitate şi morbiditate. Diferențierea dintre DFU infectat şi neinfectat rămâne o provocare în practica curentă a clinicienilor. Chiar dacă infecția este documentată, spectrul acesteia în cadrul DFU este variat: de la celulită la osteomielită. Procalcitonina (PCT), un biomarker al sepsisului, este util în diagnosticul mai multor infecții la pacienții cu diabet zaharat incluzând osteomielita. Această trecere în revistă a literaturii prezintă toate datele relevante până în prezent vis-à-vis de utilizarea $P C T$ pentru diagnosticul infecției DFU. Datele din literatură sugerează că nivelurile PCT pot ajuta clinicienii pentru a diferenția DFU infectat de DFU neinfectat precum şi pentru a diferenția infecția părților moi de infecția osoasă însă studii viitoare mai mari sunt necesare pentru confirmarea acestor date.

Correspondence to: Dimitrios Velissaris, $\mathrm{MD}, \mathrm{PhD}$

Assistant Professor at University of Patras, Greece

Internal Medicine Department, University Hospital of Patras,

Rion 26504 Greece

E-mail: dvelissaris@upatras.gr

\section{REFERENCES}

1. SINGH N, ARMSTRONG DG, LIPSKY BA. Preventing foot ulcers in patients with diabetes. JAMA 2005; 293:217-28.

2. GIURATO L, MELONI M, IZZO V, et al. Osteomyelitis in diabetic foot: A comprehensive overview. World J. Diabetes 2017 ; 8:135-142. 
3. LIPSKY BA, BERENDT AR, DEERY HG, et al. Diagnosis and Treatment of Diabetic Foot Infections. Clin. Infect. Dis. 2004; 39:885-910.

4. SCHNEIDER H-G, LAM QT. Procalcitonin for the clinical laboratory: a review. Pathology 2007; 39:383-90.

5. SCHUETZ P, CHRIST-CRAIN M, MÜLLER B. Procalcitonin and other biomarkers to improve assessment and antibiotic stewardship in infections--hope for hype? Swiss Med. Wkly. 2009; 139:318-26.

6. HAUSFATER P. Le dosage de la procalcitonine en pratique clinique chez l'adulte. La Rev. Médecine Interne 2007; 28:296-305.

7. DINH T, SNYDER G, VEVES A. Current techniques to detect foot infection in the diabetic patient. Int. J. Low. Extrem. Wounds 2010; 9:24-30.

8. GLAUDEMANS AWJM, UÇKAY I, LIPSKY BA. Challenges in diagnosing infection in the diabetic foot. Diabet. Med.2015; 32:748-59.

9. MASSARA M, DE CARIDI G, SERRA R, et al. The role of procalcitonin as a marker of diabetic foot ulcer infection. Int. Wound J. 2017;14:31-34.

10. PICHU S, PATEL BM, APPARSUNDARAM S, et al. Role of biomarkers in predicting diabetes complications with special reference to diabetic foot ulcers. Biomark. Med. 2017; 11:377-88.

11. VAN ASTEN SA, NICHOLS A, LA FONTAINE J, et al. The value of inflammatory markers to diagnose and monitor diabetic foot osteomyelitis. Int. Wound J. 2017; 14:40-45.

12. DELEVAUX I, ANDRE M, COLOMBIER M, et al. Can procalcitonin measurement help in differentiating between bacterial infection and other kinds of inflammatory processes? Ann. Rheum. Dis. 2003; 62:337-40.

13. SIMON L, GAUVIN F, AMRE DK, et al. Serum procalcitonin and C-reactive protein levels as markers of bacterial infection: a systematic review and meta-analysis. Clin. Infect. Dis. 2004; 39:206-17.

14. CHRIST-CRAIN M, MÜLLER B. Procalcitonin in bacterial infections--hype, hope, more or less? Swiss Med. Wkly. 2005; 135:451-60.

15. ASSICOT M, GENDREL D, CARSIN H, et al. High serum procalcitonin concentrations in patients with sepsis and infection. Lancet (London, England) 1993; 341:515-8.

16. AL-SHAMMAREE SW, ABU-ALKASEEM B, SALMAN I. Procalcitonin levels and other biochemical parameters in patients with or without diabetic foot complications.J. Res. Med. Sci.2017; 22:95.

17. UMAPATHY D, DORNADULA S, RAJAGOPALAN A, et al. Potential of circulatory procalcitonin as a biomarker reflecting inflammation among South Indian diabetic foot ulcers. J. Vasc. Surg. 2017; pii: S0741-5214 (17) 31127-8 (epub ahead of print).

18. INGRAM JR, CAWLEY S, COULMAN E, et al. Levels of wound calprotectin and other inflammatory biomarkers aid in deciding which patients with a diabetic foot ulcer need antibiotic therapy (INDUCE study).Diabet. Med.2017 doi: 10.1111/dme.13431 (epub ahead of print).

19. YANG Q, CAO Y, FANG Y, et al. The influence of different debridement methods on the prognosis of elderly patients with diabetic foot ulcers and sepsis. Minerva Chir. 2017; 72:200-5.

20. PARK JH, SUH DH, KIM HJ, et al. Role of procalcitonin in infected diabetic foot ulcer. Diabetes Res. Clin. Pract.2017; 128:51-7.

21. REINER MM, KHOURY WE, CANALES MB, et al. Procalcitonin as a biomarker for predicting amputation level in lower extremity infections. J. Foot Ankle Surg. 2017; 56:484-91.

22. KARAKAS A, ARSLAN E, CAKMAK T, et al. Predictive value of soluble CD14, Interleukin-6 and Procalcitonin for lower extremity amputation in people with diabetes with foot ulcers: A pilot study. Pakistan J. Med. Sci. 2014; 30:578-82.

23. JONAIDI JAFARI N, SAFAEE FIROUZABADI M, IZADI M, et al. Can procalcitonin be an accurate diagnostic marker for the classification of diabetic foot ulcers? Int. J. Endocrinol. Metab. 2014; 12:e13376.

24. MICHAIL M, JUDE E, LIASKOS C, et al. The performance of serum inflammatory markers for the diagnosis and follow-up of patients with osteomyelitis. Int. J. Low. Extrem. Wounds 2013; 12:94-9.

25. ALTAY FA, SENCAN İ, ŞENTÜRK GÇ, et al. Does treatment affect the levels of serum interleukin-6, interleukin-8 and procalcitonin in diabetic foot infection? A pilot study. J. Diabetes Complications 2012; 26:214-8.

26. MUTLUOĞLU M, UZUN G, İPCIOGLU OM, et al. Can procalcitonin predict bone infection in people with diabetes with infected foot ulcers? A pilot study. Diabetes Res. Clin. Pract. 2011; 94:53-6.

27. JEANDROT A, RICHARD J-L, COMBESCURE C, et al. Serum procalcitonin and C-reactive protein concentrations to distinguish mildly infected from non-infected diabetic foot ulcers: a pilot study. Diabetologia 2008; 51:347-52.

28. UZUN G, SOlMAZGUl E, CURUKSUlu H, et al. Procalcitonin as a diagnostic aid in diabetic foot infections. Tohoku J. Exp. Med 2007; 213:305-12.

29. VICTORIA VAN ASTEN SA, GERADUS PETERS EJ, XI Y, et al. The role of biomarkers to diagnose diabetic foot osteomyelitis. A Meta-analysis. Curr. Diabetes Rev. 2016; 12:396-402.

Received September 20, 2017 